Ks. Augustyn ECKMANN (Lublin)

\title{
„INCARNATIO CHRISTI" W PISMACH ŚWIĘTEGO AUGUSTYNA: ISTOTA I CEL
}

Człowiek został stworzony na obraz i podobieństwo Boga. Istnieje jednak ogromna różnica między Bogiem a człowiekiem, między Stwórcą a stworzeniem. Wzajemna relacja nie byłaby możliwa, gdyby ta „odległość” nie została w pewnym momencie przezwyciężona. Tę różnicę między Bogiem i człowiekiem opisuje Augustyn między innymi w liście 18 do Celestyna (napisanym ok. roku 388/390, prawdopodobnie przyszłego papieża Celestyna, do którego po jego wyborze na stolicę Piotrową skierował list 209), gdzie wyjaśnia pewne pojęcia, których używał w swych pismach Przeciw manichejczykom ${ }^{1}$ :

„Istnieje natura zmienna stosownie do miejsca i czasu, jak na przykład ciało. Istnieje także natura zmienna, ale nie stosownie do miejsca, lecz tylko zależnie od czasu, jak dusza. Istnieje wreszcie natura, która jest niezmienna ani co do miejsca, ani co do czasu. Tą niezmienną naturą jest Bóg. To co [...] jest w każdy sposób zmienne, nazywa się stworzeniem, to co niezmienne, jest Stwórcą." ${ }^{2}$

Natura człowieka zatem, jego ciało i dusza zmieniają się, podczas gdy Bóg jest niezmienny. Bóg jest, On istnieje ciągle niezmiennie. Zmienna natura człowieka może odnaleźć swą stałość tylko i wyłącznie w relacji z Boską niezmienną Istotą, z Boskim „bytem”.

W kazaniu do wspólnoty, wygłoszonym w Wielką Środę, Augustyn mówi w tym właśnie duchu filozoficznym o różnicy istniejącej między Bogiem a człowiekiem. Biskup wyjaśnia swoim słuchaczom pierwsze słowa Księgi Rodzaju: „Na początku stworzył Bóg niebo i ziemię”. Przez owo „stworzył” (fecit) - nie muszą powstawać antropomorficzne wyobrażenia Boga. Człowiek nie musi być karmiony stale mlekiem, lecz powinien otrzymywać także stały po-

${ }^{1}$ Chodzi o następujące dzieła: O obyczajach Kościoła katolickiego i obyczajach manichejskich, O prawdziwej wierze przeciwko manichejczykom, Przeciwko manichejczykom komentarz do Księgi Rodzaju, Niedokończony komentarz słowny do Księgi Rodzaju, Komentarz słowny do Księgi Rodzaju.

2 Epistola 18, 2, NBA (Nuova Biblioteca Agostiniana) 21, 86, tłum. W. Eborowicz: $S$ w. Augustyn, Listy, Pelplin 1991, 170. 
karm i dlatego Bóg nie może być przedstawiany jako istota cielesna. Ukryte w sercu wyobrażenia bożków muszą się rozpaść, kiedy człowiek zwróci uwagę na słowa Boga skierowane do Mojżesza: „Ego sum, qui sum”. Wszystko istniejące poza Bogiem, w porównaniu z Nim jest niebytem. Wszystko podlega procesowi przemiany, było lub będzie, jedynie Bóg nie jest „fuit et erit”, nie jest przeszłością ani przyszłością... Tego, co już było, już nie ma; tego, co będzie, jeszcze nie ma. A to, co przygotowuje się, by przyjść, jest przejściowe i osiągnie stadium, którego nie ma.

„Przemyślcie, jeśli możecie «Ego sum, qui sum». Nie chciejcie Go odrzucać przez wasze pożądliwości, nie chciejcie Go niepokoić waszymi swawolnymi i chwilowymi wyobrażeniami. Trwajcie przy pojęciu EST, przy ON JEST (state ad ipsum est) i przy niczym innym. Trwajcie, byście i wy mogli być. (State, ut et vos esse possitis)"

Jedynie w trwałości i niezmienności „Bytu” natura może odnaleźć swą stałość, a człowiek, który w swej istocie należy do „nie-bytów”, może w relacji z Bogiem przejść do prawdziwego „bytu”. Człowiek musi stać się tym, kim jest Bóg. Można tu z pewnością dostrzec „deificatio”, proces, który polega na ruchu wychodzącym od człowieka w kierunku Boga. Dzieje się to przez zrozumienie wyższej rzeczywistości natury Boga, Stwórcy nieba i ziemi. Ogólne ujęcie tego problemu przez Augustyna trafnie konkluduje Etienne Gilson w następujący sposób: „ «Niebyt», «Nic» musi przestać stawać się sobą samym, musi w końcu stać się bytem, musi ostatecznie stać się bogiem" ". Gilson znajduje w całej tej myśli Augustyna podobne ujęcie problemu, jaki prezentuje współczesny egzystencjalizm, jednak Augustyn widzi rozwiązanie całego tego problemu w „bycie” i w czasie, w Ewangelii i we wierze.

Na pytanie, czy dla człowieka istnieje tylko jedna możliwość, aby w ten sposób nawiązać kontakt i przez to dojść do poznania Boga, Augustyn odpowiada zdecydowanie „tak”: droga do tego celu prowadzi przez Boskie miłosierdzie. Bóg ulitował się i objawił się Mojżeszowi mówiąc: „Ego sum, qui sum”, wiedząc, że Mojżesz jest człowiekiem, który podlegał procesowi przemijania; człowiekiem, który nie pojmował pełnego znaczenia tych słów, dlatego też Bóg dołączył imię: „Ego sum Deus Abraham, et Deus Isaac, et Deus Jacob", które Mojżesz dobrze rozumiał. Pierwsze określenie jest nazwaniem natury Boga, Jego istoty, substancji. Drugie jest określeniem Jego miłosierdzia. Jednakże Bóg Abrahama, Izaaka i Jakuba jest Bogiem, „qui est”, jest wieczny. Bóg może być nazwany Bogiem Abrahama, Izaaka i Jakuba jedynie dlatego, ponieważ On uczynił Abrahama, Izaaka, Jakuba uczestnikami wiecz-

${ }^{3}$ Sermo Denis 2, 5, MA (Miscellanea Agostiniana. Testi e studi, vol. I: Sancti Augustini sermones post Maurinos reperti, Roma 1930) I 16.

${ }^{4}$ E. Gilson, Philosophie et incarnation selon Saint Augustin, Montreal 1947, 52. 
ności ${ }^{5}$. Poznanie Boskiej istoty jest więc możliwe jedynie wtedy, jeśli Bóg objawi się człowiekowi jako Bóg miłosierny i sam wyniesie go do wieczności. Takie samo wyjaśnienie Wj 3, 13-15 daje Biskup w Sermo 6: Człowiek może poznać „Byt” dzięki wcieleniu. Poznanie Boga jest możliwe, ponieważ Syn Boży przyjął ciało ${ }^{6}$. Incarnatio Christi jest objawieniem Boskiej Istoty. Miłosierdzie Boga doprowadza człowieka do poznania prawdziwego „bytu”, to jest zamiast stałego i solidnego pożywienia otrzymuje mleko. Augustyn przywołuje przykład matki karmiącej niemowlę. Ponieważ dziecko nie może jeszcze spożywać stałych posiłków, matka przyjmuje je i przetwarza w swoim ciele i je jak gdyby ,inkarnuje" tak, iż staje się ono odpowiednie dla niemowlęcia. Podobnie i Bóg - Słowo staje się ciałem, aby móc stać się odpowiednim dla człowieka jako niemowlęcia. Stałe pożywienie znajduje się w słowach: „In principio erat Verbum et Verbum erat apud Deum". Ten stały pokarm spożywają aniołowie, a człowiek z powodu swej słabości nie mógłby sam z siebie do tego dojść. Dlatego Słowo stało się ciałem, aby człowiek mógł je zrozumieć ${ }^{7}$.

Aby człowiek mógł dojść do poznania Boga, dzięki któremu mógł wejść do Boskiego „Bytu”, potrzebne było wcielenie. Bóg musiał skłonić się w kierunku człowieka. Bezpośrednia znajomość Boga i bezpośredni kontakt ze Słowem (Verbum), jaki istniał na początku był jedynie udziałem aniołów. Człowiek potrzebował Słowa, które stało się ciałem - Jednorodzonego Syna, który jest w łonie Ojca i który objaśnił człowiekowi istotę i naturę boskości ${ }^{8}$. Chrystus mógł to uczynić, ponieważ był Słowem Boga ,przez które zostały stworzone

5 Por. Sermo Denis II, 5.

${ }^{6}$ Por. Sermo 6, 1, NBA 29, 96: ,non enim maiestas illa, quae fecit caelum et terram, quae regit universum mundum, cui semper inhaerent angeli contemplando eius pulchritudinem mentibus puris, oculis autem hominis mortalibus potuit apparere, nisi assumpta visibili et sensibili creatura quae ad istos oculos visibiles corporis pertinet, quando quidem et ipsa Sapientia Dei, per quam facta sunt omnia, humanis oculis non appareret nisi mortalem, carnem assumeret"; zob. też Sermo 4, 5, tamże s. 30-32, oraz Sermo 7, tamże s. 106-116.

${ }^{7}$ Por. C. Lambot, Sermons inédits de S. Augustin 2, 4, RBen 59(1949) 71-72; Sermo 59, 3 i 6, NBA 30/1, 204: „Et verbum Dei quod quotidie praedicatur panis est. Non enim quia non est panis ventris, ideo non est panis mentis. Cum autem vita ista transierit nec panem illum quaeremus quem quaerit fames; nec sacramentum altaris habemus accipere, quia ibi erimus cum Christo cuius corpus accipimus; nec verba ista nobis dici habent quae dicimus vobis nec codex legendus est, quando ipsum videbimus quod est Verbum Dei, per quem facta sunt omnia, quo pascuntur angeli, quo illuminantur angeli, quo sapientes fiunt angeli, non quaerentes verba locutionis anfractuosae, sed bibentes unicum Verbum et inde impleti ructant laudes, et non deficiunt in laudibus"; Sermo 57, 7 i 7, NBA 30/1, 170-172: „Numquid illuc quando venerimus, codicem sumus audituri? Ipsum Verbum visuri, ipsum Verbum audituri, ipsum manducaturi, ipsum bibituri, quomodo angeli modo. Numquid illuc quando venerimus, codicem sumus audituri? ipsum verbum visuri, ipsum verbum audituri, ipsum manducaturi, ipsum bibituri, quomodo angeli modo. Numquid angelis codices sunt necessarii,aut disputatores, aut lectores? Absit. Videndo legunt: vident enim ipsamVeritatem, et illo fonte satiantur, unde nos irroramur".

${ }^{8}$ Por. Epistola 147 De videndo Deo liber 37, NBA 22, 408-410. 
wszystkie rzeczy". Również On jest niezmienny i pozostanie niezmienny przy niezmiennym Ojcu. Ponieważ On sam objawił się w ciele, pozostanie On wszechwieczny aż do końca świata wraz ze swym Ojcem. Przez kontakt z Nim człowiek również nawiązuje więź z niezmienną Mądrością, przez którą świat został stworzony, a przez udział w Mądrości każda dusza staje się błogosławiona'.

Wielka różnica między Bogiem a człowiekiem tkwi nie tylko w naturze, w substancji, w istocie, w „bycie” czy „nie-bycie”, lecz również w moralności. Bardzo często mówi Augustyn o tej różnicy. Istnieje kazanie, w którym Biskup bardziej aniżeli w przytoczonych kazaniach i listach porusza się na poziomie zwykłego członka Kościoła. Tego rodzaju jest Sermo 171, w którym Augustyn mówi:

„Czy istnieje coś tak odległego od siebie jak Bóg od ludzi, Nieśmiertelny od śmiertelnych, Sprawiedliwy od grzeszników? Nie daleko pod względem miejsca, lecz niepodobieństwa (non loco longe, sed dissimilitudine). Zwykliśmy bowiem tak się wyrażać, gdy mówimy o dwóch osobach z różnymi obyczajami, które są daleko od siebie: i tak pobożny jest daleko od bezbożnika, niewinny daleko od winnego, sprawiedliwy daleko od niesprawiedliwego. Jeśli tak mówimy o ludziach, to jakże znamienny jest przypadek wzajemnego stosunku między Bogiem a człowiekiem? I chociaż Bóg jako nieśmiertelny i sprawiedliwy stoi daleko od człowieka, ponieważ człowiek jest grzeszny i śmiertelny, to jednak Bóg zstąpił do nas, aby będąc daleko stał się nam najbliższy." 10

Bóg jest sprawiedliwy, podczas gdy w człowieku tkwią dwie wady: grzeszność i śmiertelność, pierwsza jest winą (culpa), a druga karą (poena). Winą jest to, że człowiek jest grzeszny, niesprawiedliwy, a karą za jego grzeszność jest śmiertelność. Aby być bliżej człowieka Chrystus przyjął karę, ale nie przyjął winy. Tym uczynkiem zmazał winę i karę.

Moralne niepodobieństwo między Bogiem a człowiekiem jest dla Augustyna równie istotne, jak fizyczne. Dlatego wcielenie miało to na celu, aby znieść ową moralną różnicę. Zdaniem Augustyna chodzi w pierwszym rzędzie przede wszystkim o zgładzenie moralnego niepodobieństwa, ponieważ różnica co do istoty - śmiertelność - jest $\mathrm{z}$ nią związana.

W tym celu, by pokonać przepaść między Bogiem a człowiekiem został dany ludziom mediator - pośrednik. Pośrednikiem jest Ten „per quem conjungeremur, per quem reconciliaremur: quia peccatis propriis separati jacebamus, in morte eramus, prorsus perieramus" ${ }^{11}$. Pojednanie więc znaczy tyle, co uzys-

${ }^{9}$ Por. Epistola 102, 2 i 11, NBA 21, 960 i 362.

${ }^{10}$ Sermo 171, 3, NBA 31, 2, 822.

11 Sermo 2, 7, NBA 29, 502-504; zob. Epistula 140, 26 i 68, NBA 22, 284: „pro hoc enim mediator effectus est, ut nos reconciliet Deo per humilitatem , a quo per impiam superbiam longe recesseramus". 
kanie łączności między Bogiem i człowiekiem po zniesieniu dysproporcji pod względem natury i moralności.

„Nasz Pan i Zbawiciel Jezus Chrystus, w którym pokładamy nadzieję na życie wieczne, będąc Bogiem stał się czlowiekiem po to, by człowiek, który stał daleko od Boga, nie myślał nigdy więcej, że jest od Niego daleko, opuszczony i pozostawiony samemu sobie. Dlatego Chrystus stał się pośrednikiem i czas oczekiwania (longinquitas) od chwili stworzenia nas przez Boga wypełnił się w ten sposób, tak iż dzięki Niemu nie jesteśmy już sami i nie pozostajemy nadal daleko od Boga, lecz w rzeczywistości możemy być również bliżej Niego [...] Słowo stało się ciałem i połączyło człowieka z Bogiem (Verbum factum est caro, et coniunxit hominem Deo) $" 12$.

To połączenie było możliwe dzięki boskiej i ludzkiej naturze Chrystusa. Bez boskości nie mógłby być On jako człowiek pośrednikiem, „sed inter divinitatem solam et humanitatem solam, mediatrix est humana divinitas et divina humanitas Christi" "13. Będąc człowiekiem Chrystus posiadał taką samą naturę, jak inni ludzie, również jego dusza nie różniła się od dusz ludzkich. Przyjął tę naturę, ponieważ dzięki niej mógł być ratunkiem. Jednakże nie nosił w sobie żadnej winy, bo Jego natura była ", pura, sed non sola humana"14. Nie znaczy to, że słabość ciała zmieniła Go samego, lecz przeciwnie - owa słabość ciała zmieniła się dzięki Niemu na dobre. On to uświęcił ciało i zmienił człowieka w Siebie samego ${ }^{15}$. W wyniku wcielenia Słowo nie przestało istnieć, lecz ciało dostąpiło Słowa, tak iż ciało nie uległo zagładzie ${ }^{16}$.

Augustyn uznaje w ten sposób wraz z całym Kościołem katolickim dwie natury: boską i ludzką w Chrystusie. Sensem i celem wcielenia było więc uzyskanie kontaktu między Bogiem i człowiekiem. Dzięki wcieleniu śmiertelna natura człowieka uległa przemianie na coś lepszego. Bóg po to stał się człowiekiem, by człowiek mógł poznać swe własne człowieczeństwo: „homo factus est, ut se homo hominem cognosceret". Wcielenie widzi więc jako środek przeciw ludzkiej pysze i zarozumiałości. Bóg odsunął swoją boskość, to znaczy ukrył swą własną istotę. Bóg stał się człowiekiem, aby przez to człowiek mógł rozpoznać, że jest człowiekiem, że jest słaby, grzeszny, że jest chory i jako chory może zwracać się do swego Lekarza ${ }^{17}$.

W pokorze Chrystusa człowiek winien rozpoznać i uznać własną grzeszność i śmiertelność, aby dzięki wyznaniu grzechów dojść do Boga. Chrystus, który stał się człowiekiem, jest dla człowieka jedyną i wyłączną drogą do Boga. Człowiek, trwający w pokornym Chrystusie, zostanie umocniony w wywyższo-

\footnotetext{
12 Sermo Guelferbytanus 28, 1, MA I 535-536.

13 Sermo 47, 12, 21, NBA 29, 900.

14 Sermo 174, 2, 2, NBA 31/2, 842.

15 Por. Sermo 12, 12, NBA 29, 226-228.

16 Por. Sermo 186, 1, NBA 32/1, 12, PSP 12, 27.

17 Por. Sermo 77, 7, 11, NBA 30/1, 538.
} 
nym Chrystusie. Tylko słabość człowieka jest przyczyną zniżenia się Chrystusa. Przyszedł On nauczyć człowieka pokory, aby człowiek w ten sposób mógł powrócić do Boga ${ }^{18}$.

Przez rozpoznanie boskości w pokornym Chrystusie, człowiek może powrócić do życia. Pokora Chrystusa jest „nadzwyczajna” i błogosławiona zarazem, ponieważ nasza wiara składa się z ,rzeczy nadzwyczajnych” (ex incredibilibus enim constat fides nostra). Cała inkarnacja, Bóg ukrzyżowany (Deus crucifixus) i zmartwychwstanie są rzeczami „niesłychanymi”, lecz to wszystko oznacza dla człowieka zbawienie. Chrystus przyszedł jako mediator-pośrednik, w całej swej uniżoności i powoływał ludzi do swej boskości (vocans illum ad divinitatem suam), brał udział $w$ ich cierpieniu i sam poniósł śmierć na krzyżu, aby dać nam życie. ${ }^{19}$

W pokorze, we wcieleniu, jak i w śmierci Chrystusa, leży powołanie człowieka do boskości. Drogą dla człowieka jest naśladowanie pokornego Chrystusa. Cierpienia mogą okazać się korzystne dla człowieka, jeśli będzie Chrystusa naśladował. Oprócz wytrwania w męczeństwie, może człowiek naśladować Chrystusa w pokorze i posłuszeństwie „usque ad participationem mortalitatis humanae”. Co więcej? „Ascendit Christus in coelum: sequamur eum”. Należy wzgardzić tymczasowością i doczesnością. Ten, kto tak czyni, jest pewny, że kroczy ścieżkami Chrystusa i może śmiało powiedzieć: „,conversatio nostra in coelis est”20.

Do tej przedziwnej ,imitatio Christi” dochodzi również „purgatio cordis”, w wyniku czego Bóg może być osiągalny w sposób intelektualny. „Purga mentem, purga cor tuum. Mundum fac oculum, unde illud quidquid est, possit attingi" - napomina św. Augustyn. Nie widzimy Boga, lecz możemy duchem lub wewnętrznym okiem oglądać Boskie serce. To wszystko stało się możliwe dzięki inkarnacji.

„Słowo, dzięki któremu wszystkie rzeczy zostały stworzone, stało się tym, kim jesteśmy, abyśmy mogli osiągnąć to, czym nie jesteśmy"21.

W ten sposób Augustyn powiedział dokładnie to samo, co już występuje w Quod idola dii non sint św. Cypriana, mianowicie iż Chrystus stał się tym, kim jest człowiek po to, by człowiek stał się tym, kim On jest. ${ }^{22}$ Jest to stawanie się Chrystusem, a więc „deificatio”, bo Chrystus jest również Bogiem. Nie jest to związane wyłącznie z tym, iż Chrystus stał się człowiekiem, ponieważ dla Augustyna cała działalność Chrystusa jest ważna, również Jego życie jako człowieka, zarówno Jego śmierć i zmartwychwstanie. Cały proces zbawienia

18 Por. Sermo Wilmart 11, 2, MA I 695.

19 Por. Sermo Mai, 22, 1, MA I 314-315.

20 Sermo 304, 3, 3, NBA 33, 520.

21 Sermo 117,15 , NBA 31/1,22.

22 Por. Quod idola dii non sint 11-15, CSEL 3/1, 28-31, thum. M. Kondratowicz: Święty Cyprian, Pogańskie bóstwa nie są bogami, VoxP 11-12(1991-1992), z. 20-23, 446-449. 
przez Chrystusa objawia się w przedziwny sposób w człowieku: z jednej strony przez wiarę, naśladowanie Zbawiciela (imitatio Christi); z drugiej - w ścisłym związku z powyższym - w sposób sakramentalny przez oczyszczenie i odrodzenie. Biskup stwierdza: „nisi haberet ille humanam generationem, nos non perveniremus ad divinam regenerationem"23.

Ponowne nawrócenie jest zdaniem Augustyna nierozerwalnie związane z chrztem. „Humana generatio” oznacza narodziny Chrystusa jako człowieka, a „divina regeneratio” - ponowne narodzenie człowieka jako „istoty boskiej” przez chrzest. Nie ulega żadnej wątpliwości, że „incarnatio” sprawia "deificatio" człowieka. Oprócz tego, że wynika to z refleksji poczynionych powyżej, wypływa to również z formuły, która w pismach Augustyna często się powtarza: „Venit, factus est homo particeps mortalitatis nostrae, ut nos possimus fieri participes immortalitatis ipsius" ${ }^{24}$. Chociaż Chrystus przyjmuje ludzką postać, spożywa jak inni ludzie chleb, to jednak są oni przez Niego pojednani z Bogiem. Św. Augustyn pisze o tym w liście 187, kiedy mówi o Kościele jako Ciele Chrystusa, którego Chrystus jest Głową:

„Poprzez naszą Głowę jesteśmy pojednani z Bogiem, ponieważ przez nią boskość Jednorodzonego stała się uczestnikiem naszej śmiertelności, żebyśmy i my mogli mieć udział w Jego nieśmiertelności” ${ }^{25}$.

Położony więc został związek między pojęciem nieśmiertelności, a całym Ciałem Chrystusa, którym jest Kościół.

To samo można odnaleźć w obrazie, jakim Augustyn posługuje się, mówiąc o dziełach Chrystusa, mianowicie o „mercatio". Pan chciałby, żeby ludzie stawali się w ten czy inny sposób „mercatores” - handlującymi, którzy wymieniają między sobą różne towary. Jedni dają to, co mają w nadmiarze, otrzymując w zamian to, czego im brak.

„Co dajemy, a co otrzymujemy? Chcielibyśmy dać to, czego sami nie możemy się pozbyć. Dajemy ziemię, a otrzymujemy niebo. Dajemy doczesność, a otrzymujemy wieczność, dajemy ułomność, zepsucie, a otrzymujemy doskonałość. Krótko mówiąc dajemy to, co Bóg nam dał, aby w zamian otrzymać samego Boga ${ }^{26}$.

Jak jest niemożliwe, aby Chrystus nie umarł w Nim samym, tak nie jest możliwe, by człowiek żył z siebie samego: „O magna mutatio. Vive de ipsius quia de tuo mortuus est"27.

23 Sermo Frangipane 4, 3, MA I, 210-211.

24 Sermo Caillau et Saint-Yves 2, 19, 8, MA I 271.

25 Epistola 187, 20, NBA 23, 150: „Per caput nostrum reconciliamur Deo, quia in illo est divinitas Unigeniti facta particeps mortalitatis nostrae, ut et nos participes eius immortalitatis essemus".

26 Sermo 177, 10, PL 38, 959.

27 Sermo Morin 17, 7, MA I 664; por. Sermo Guelferbytanus 3, 1; Sermo Denis 5, 5. 
Śmierć Chrystus miała miejsce dlatego, by mogła być w pewnym sensie wynagrodzeniem (compensatio) w niebie w swego rodzaju transakcji handlowej (coelestis... mercimonii) tak, by człowiek nie widział śmierci ${ }^{28}$. Bóg stał się człowiekiem, by człowiek mógł się zmienić. Co Augustyn już kilkakrotnie powtarzał, jeszcze raz mówi wyraźnie: Chrystus stał się człowiekiem, by człowiek stał się bogiem:

„To dla was Twórca czasu został uczyniony w czasie, to dla was Założyciel świata oblekł się w ciało, to dla was Stwórca przybrał postać stworzenia. Dlaczego wy jeszcze jako śmiertelni dajecie się zwabiać rzeczami doczesnymi i próbujecie zatrzymać, o ile to tylko możliwe, wasze przemijające życie? Nad ziemią zabłysła o wiele bardziej jaśniejąca nadzieja, aby obiecać istotom ziemskim życie w niebie. Aby to uznano, przyznano rzecz niesłychaną. Ten, który był Bogiem, stał się czlowiekiem, aby tych, którzy są ludźmi, uczynić bogami. On tymczasem nie tracąc tego, czym był przedtem, wolał stać się tym, co wcześniej uczynił”29.

Tę myśl można postawić obok wyrażenia św. Atanazego: Bóg stał się człowiekiem, aby człowiek mógł być ubóstwiony. ${ }^{30}$

Również na innym miejscu można spotkać myśl, że człowiek przez inkarnację stał się bogiem, między innymi wtedy, gdy człowiek dzięki inkarnacji staje się uczestnikiem dziecięctwa Bożego. Słowo stało się ciałem, i tym, którzy wierzą w Jego imię, sprawia, że stają się dziećmi Bożymi: „Nolite putare multum esse ad vos, fieri filii Dei: propter vos Filius hominis factus est, qui erat Filius Dei". ${ }^{31}$

Dystans między Bogiem a człowiekiem polega na różnicy istoty i moralności. Bóg w swej istocie jest całkiem inny aniżeli człowiek, ponieważ On jest wieczny, podczas gdy człowieka cechuje przemijalność. Ta przepaść zostaje pokonana za sprawą Bożego miłosierdzia, a przez wcielenie zostaje stworzona dla człowieka droga prowadząca do poznania Boskiej Istoty. Człowiek, który przez grzech (upadek) stał się „nie-bytem”, zostaje wyniesiony do „Bytu”. Na

${ }^{28}$ Sermo 80, 5, NBA 30/1, 586.

29 Sermo 192, 1, NBA 32/1, 50: „Propter vos temporalis effectus est temporum effector, propter vos in carne apparuit mundi Conditor, propter vos creatus est Creator. Quid adhuc mortales mortalibus rebus oblectamini, et fugitivam vitam, si fieri posset, tenere conamini? Spes longe clarior effulsit in terris, ut terrenis vita promitteretur in coelis. Hoc ut crederetur res incredibilior praerogata est. Deos facturus qui homines erant, homo factus est qui Deus erat: nec amittens quod erat fieri voluit ipse quod fecerat".

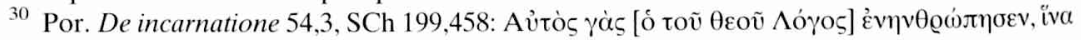

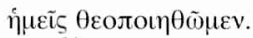

${ }^{31}$ Sermo 119,5 , NBA 31/1, 36. 
tym zasadza się „deificatio”. Oznacza to, że ludzka słabość musi się zmienić w nieśmiertelność, jak również musi zostać zniesiony kontrast pod względem moralnym między Bogiem, który jest sprawiedliwy, a grzesznym człowiekiem. Również i to dokonuje się przez cudowne dzieła Chrystusa, przez którego zostaje przywrócona jedność między Bogiem a człowiekiem mocą Jego pośrednictwa. On sprawia, że człowiek jako istota cielesna, wchodzi w kontakt z tym, co boskie, i co umożliwia człowiekowi współuczestnictwo w boskiej nieśmiertelności. Formuła atanazjańska: „Bóg stał się człowiekiem, aby człowiek mógł stać się bogiem" ujmuje w zasadzie to wszystko, co również ma do powiedzenia św. Augustyn o istocie i celu inkarnacji.

\section{L'INCARNAZIONE DI CRISTO NEGLI SCRITTI DI SANT'AGOSTINO. ESSENZA E SCOPO}

(Riassunto)

L'autore dell'articolo spiega che la distanza tra Dio e l'uomo è stata colmata attraverso l'incarnazione del Figlio di Dio. Grazie all'incarnazione è stata creata per l'uomo la via alla conoscenza dell'essenza divina. Attraverso le opere miracolose di Cristo è stato eliminato il contrasto morale tra Dio e l'uomo. 